\title{
READING THAUMA: PARADOXOGRAPHY AND THE TEXTUAL COLLECTION OF MARVELS
}

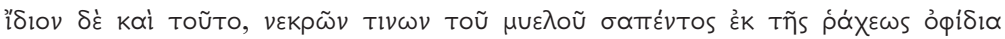

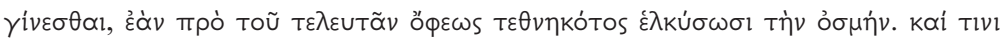

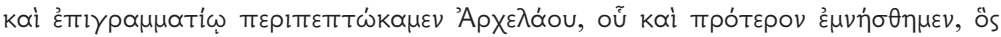

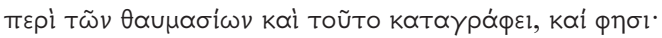

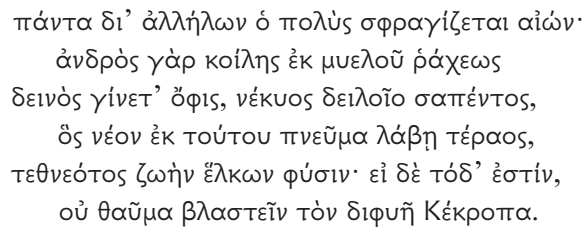

And this is also strange: little snakes are born out of the rotten spinal marrow of dead men if they breathe in the stench of a dead snake before death. And I have encountered an epigram on this theme by Archelaus, whom I mentioned before, who writes on marvels and says this:

Long life puts its own stamp on each thing, marking one by another,

for from the marrow of the hollow spine of a man

a terrible snake is born, from a wretched corpse that has rotted away,

a snake which draws new breath from this prodigy,

dragging a living nature from a dead man: and if this is the case,

it is no wonder that the bi-formed Cecrops blossomed forth.

Antigonus of Carystus, Collection of Marvellous Investigations 89

By the time we reach this graphic poetic account of spontaneous generation by Archelaus the Egyptian, cited in a Hellenistic paradoxographical collection attributed to Antigonus of Carystus (fl. c. 240

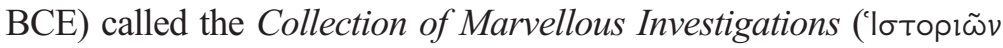
$\pi \alpha \rho \alpha \delta o ́ \xi \omega \nu \sigma u v \alpha \gamma \omega \gamma \eta \dot{)}$ ), the reader has already encountered eightyeight tantalisingly brief accounts of equally enigmatic thaumata. ${ }^{\mathrm{I}}$

I This paradoxographical collection survives in a single ms. copy (Cod. Pal. graec. 398), now in Heidelberg. See PGR 32-II5 for the remaining fragments. The name 'Antigonus' is inscribed at the collection's opening and most probably refers to Antigonus of Carystus, a 
Without any explanation or reasoning, we have been repeatedly asked to marvel at many brief and bizarre accounts of zoological wonders. The customary extreme brevity and unexpected lack of contextual detail included in each marvel becomes clearer from a few examples. For instance, we are told that 'near the regions of Carystia and Andria there is an island called Gyaros: the mice gnaw through iron there'

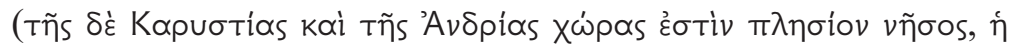

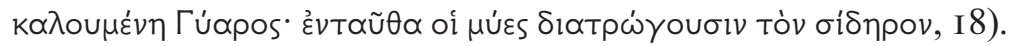
Later we are informed that 'as soon the sun starts to go down, nanny

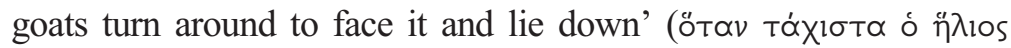

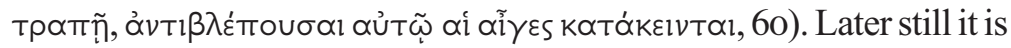
revealed that 'in Phrygia there are oxen which wiggle their horns' ( $\varepsilon v$

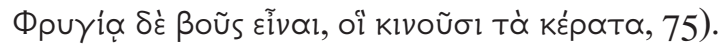

Compared to the usual brief entries in Antigonus' collection, the epigram cited above, by the author Antigonus has earlier

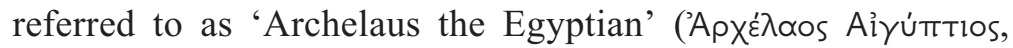
I9), is certainly a longer and more obviously artful treatment of paradoxical themes than most other entries in this marvelcollection. ${ }^{2}$ Read in isolation, Archelaus' epigram appears to represent a typically Hellenistic poetic production, a skilful transformation of a bizarre scientific theory concerning spontaneous generation into a more refined poetic form comparable with Posidippus' transformation of Peripatetic scientific prose into artful epigrams in his Lithika, or Aratus' recasting of Eudoxus of Cnidus' scientific astronomical prose treatise into hexameters

\footnotetext{
third-century BCE author associated with the court at Pergamon, who wrote a work entitled Lives of Philosophers and probably also produced treatises on sculpture, art history and diction. Musso (I976) I-IO, (I977) I5-I7 and (I985) 9 argues against Antigonus' authorship of the Collection of Marvellous Investigations and suggests that it is the product of later Byzantine scholarship, but the dating of at least the core of the collection to the third century BCE seems secure, as all of the authors cited date from either the time before Antigonus of Carystus was active or are roughly contemporaneous with him. Dorandi (I999) xi-xxxii and (2005) I2 I-4, believes that the attribution to Antigonus of Carystus is uncertain and suggests that another unknown Antigonus may be the author. Although it is not possible to attribute the collection to Antigonus of Carystus with certainty, the arguments for Antigonan authorship put forth by Wilamowitz (I88I) I6-26 remain compelling (cf. Schepens and Delcroix (I996) 4OI n. 89): as a result, I refer to the author of this paradoxographical collection as Antigonus of Carystus here, though none of my arguments depend on this attribution.

2 Archelaus the Egyptian is also known as Archelaus of Chersonesus (see e.g. Athenaeus

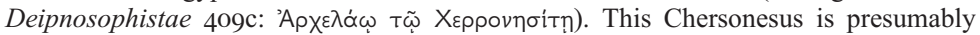
Chersonesus Mikra, an Egyptian settlement very close to Alexandria (see e.g. Strabo Geography I7.I.I4).
} 
in his didactic Phaenomena. ${ }^{3}$ For the modern reader, it is perhaps tempting to excerpt this excerpted epigram of Archelaus from its broader context, ignoring the surrounding paradoxographical prose and the relation of that text to the more polished lines of verse which follow. This temptation becomes stronger if we examine the entries which come before and after Archelaus' epigram. The preceding prose entry clearly anticipates the theme of spontaneous generation which the epigram explores by presenting us with an instance of a living body expelling another living biological form of a completely different species. This marvel, however, is presented very differently from Archelaus' polished verse (Collection 88):

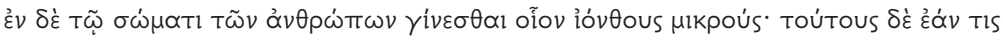

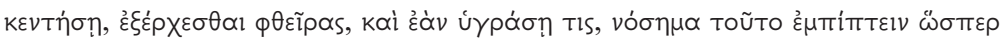

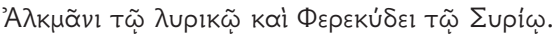

Small boils appear on men's bodies. And if someone pricks these, lice come out. And if someone has a moist nature, this illness befalls them, just as happened to Alcman the lyric poet and Pherecydes of Syros.

This prose marvel ultimately derives from a longer passage in Aristotle's Historia animalium (556b28-557a3), which Antigonus has here abbreviated and adapted before turning to Archelaus' much more stylistically polished epigram on a similar theme concerning the generation of one biological form from another. In fact, it is to Aristotle's Historia animalium (557b6-8) that Antigonus turns once again as a source for the ninetieth entry in his marvel collection after the citation of Archelaus' epigram. This entry consists of a single sentence, and once more puts the wondrous process of spontaneous generation under the spotlight: 'Aristotle says that an animal is born in wax, which seems to be the smallest animal and is called akari

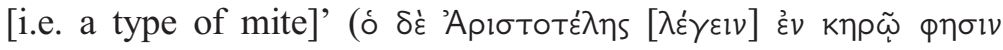

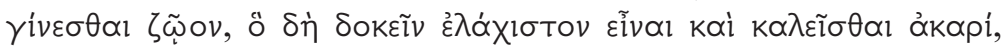
Collection 90).

These three consecutive marvels are typical of Antigonus' method throughout his Collection of Marvellous Investigations.

3 On the use of verse in prose paradoxographical collections, and the effect of prosimetrum which sometimes ensues, see Schepens and Delcroix (I996) 399 and Bartoňková (I999) 63-7. 
They encapsulate some of the issues which modern readers have faced when presented with Antigonus' work. Why does the paradoxographer choose to cite and adapt these texts where and when he does? Is there any point and purpose in his choices and his method of ordering his material? Is there anything really wondrous about the material he chooses to focus on at all?

These questions have proved difficult to answer. Like many later miscellanistic texts, Antigonus' Collection has primarily been seen as a random assemblage of knowledge with no overriding literary purpose: a mess of texts fit only to be mined and plundered for the occasional useful snippet of geographical or prosopographical information, or an intriguing textual variant, or a few precious lines of poetry. This approach has led to many misunderstandings about the nature of these texts. These have been compounded by the perceived failure of paradoxographical collections to fit in with preconceived generic norms of ancient historiography or scientific prose literature, two modes of writing with which paradoxographical collections have been seen to share certain similarities, in terms of both thematic focus and style. Furthermore, the perceived difficulty of discerning any immediately explicit aesthetic principles behind the composition of these texts has only exacerbated matters further. As the entries from paradoxographical collections cited throughout this chapter demonstrate, the reasons behind the paradoxographer's presentation and arrangement of material are not immediately obvious to the reader. As a result of all of these factors, it would be an understatement to say that Hellenistic paradoxographical collections have not enjoyed high critical esteem in recent centuries.

But to berate these texts for their failure to conform to supposed standards of ancient historiography or scientific and technical treatises is to miss the point entirely. The paradoxographical collection aims first and foremost to make the reader marvel, and the very form of these texts is inextricably tied up with this aim. In this chapter it is precisely the nature, purpose and poetics of these paradoxographical collections which will be re-examined, in order to demonstrate that as texts which, as products of excerption and radical abbreviation, are very self-consciously created out of other texts, these purely textual thaumata ask us to wonder at the new possibilities provided by the 
world of the Hellenistic library, as much as at the oddities of the natural world. The paradoxographer's principles of arrangement may seem opaque at first glance, but a closer look will reveal that there is more to these texts than first meets the eye.

In the first section of this chapter, the range and scope of the material included in extant paradoxographical collections will be assessed and previous approaches to paradoxography in modern criticism briefly outlined. In the second section, the renewed interest in literary collections of natural thaumata in the early Hellenistic court of the Ptolemies will be examined in relation to a concomitant increase in the production, collation and collection of textual thaumata which took place in Alexandria during this same period. Sections three and four then turn to the relationship between the Hellenistic paradoxographical collection and its two most influential generic antecedents, ethnography and the Peripatetic writings of Aristotle's followers. The chapter concludes with a brief assessment of the relation of the paradoxographical collection to other general trends exhibited in Hellenistic texts of other literary genres.

\section{I Collecting Thaumata: The Emergence of the Paradoxographical Collection}

Paradoxographical collections, which are essentially catalogues of marvels presented to the reader with little contextual information and seldom any authorial comment, begin to appear in the early Hellenistic period. The term 'paradoxographer' was not used in the Hellenistic period and is not found until the Byzantine age, where it first appears in the work of the twelfth-century scholar John Tzetzes

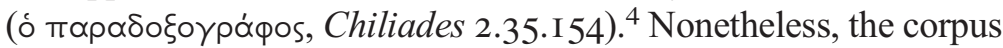
of these texts, when viewed together, reveals certain formal rhetorical properties and features which show that we are dealing with a well-defined mode of writing. The titles of these collections, which often include terms such as 'collection of marvels'

4 It was Westermann's edition (I839) which introduced the term paradoxography to the modern world. Cf. Wenskus (2000) 309-I2 on the history of paradoxography. Giannini's edition (I966) similarly groups collections of marvels under the term 'paradoxography'. On the notion of paradoxography as a distinct literary genre in antiquity see, Pajón Leyra (20II). 


\section{I The Emergence of the Paradoxographical Collection}

( $\theta \alpha \cup \mu \alpha \dot{\tau} \omega \nu \nu / \theta \alpha \cup \mu \alpha \sigma i \omega v \sigma u v \alpha \gamma \omega \gamma \eta$ ), 'collection of things contrary to

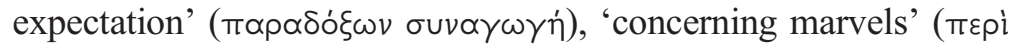

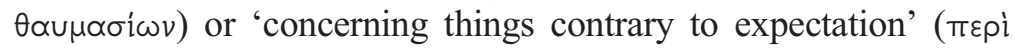
$\pi \alpha \rho \alpha \delta \delta$ $\xi \omega \nu)$, are preserved in ancient testimonia and suggest that the capacity of the entries contained within to provoke wonder is the primary focus of this mode of writing. ${ }^{5}$ In their earliest form, these marvel-catalogues consist predominantly of strange zoological or geological observations which are starkly juxtaposed to one another. ${ }^{6}$ These observations are cited from the works of previous (usually named) prose or verse authors, and are almost always completely devoid of any explanatory context. It is this lack of context which often renders the entries surprising and seemingly inexplicable. The paradoxographer does not claim to have undertaken autoptic research to confirm the truth of these thaumata, and the evidence behind each wondrous observation reported is almost always entirely neglected. Instead, the name of the original textual authority in which the thauma has been found is often included as an authorising gesture which implicitly guarantees the marvel's veracity. $^{7}$

The first paradoxographical collection of which we have knowledge was produced by Callimachus in Alexandria: it is possible that he invented this mode of writing. The marvels in Callimachus' collection seem to have focused mainly on rivers and geological oddities and were arranged geographically. This is reflected in the collection's title, Collection of Marvels from Every Land Arranged

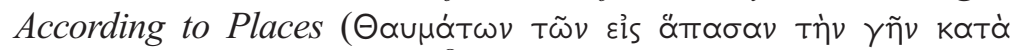

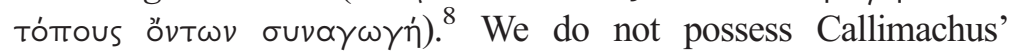

5 See Schepens and Delcroix (I996) 380 on the emergence of marvel-collections with titles along these lines in the Hellenistic period. See each author entry in $P G R$ for testimonia of the titles of the respective paradoxographical collections. The titles of later Roman marvel-collections seem to have followed a similar pattern: the title of Cicero's Admiranda is preserved in Pliny's HN (3I.I2; 3I.5I), and Varro's Gallus de admirandis in Macrobius (Sat. 3. I 5.8). For a detailed overview of the lexicon of the marvellous used within paradoxographical collections, see Pajón Leyra (20I I) 4I-50.

${ }^{6}$ Peculiar ethnographic thaumata are very occasionally included, though this is extremely uncommon in the earliest collections. The move towards the inclusion of ethnographic entries in paradoxographical collections does, however, become more common as time goes on.

7 See Schepens and Delcroix (I 996) 382-9 on the inclusion of source 'citations' as a means of emphasising the credibility of the marvels reported in paradoxographical collections.

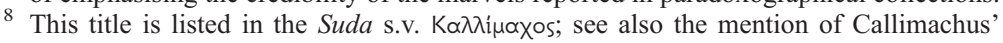

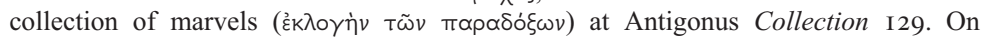




\section{Reading Thauma}

marvel-collection in its entirety, but a sizable chunk of it is excerpted and used in Antigonus' Collection of Marvellous Investigations (entries I29-73). ${ }^{9}$ Antigonus introduces the Callimachean material in entry I29 of his own collection as follows:

I 29. Tहтої

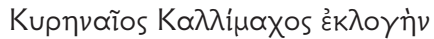
$\tau \tilde{\omega} \nu \pi \alpha \rho \alpha \delta$ ó $\omega \nu, \tilde{\eta} \varsigma$

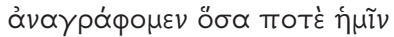

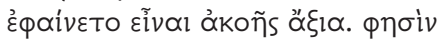

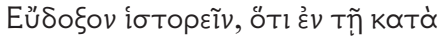

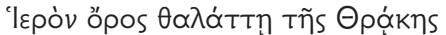

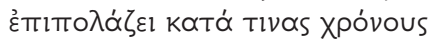

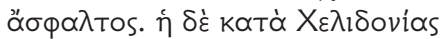

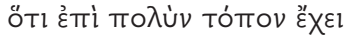

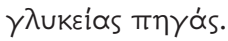

And Callimachus the Cyrenaean has also made a collection of marvels, from which I have recorded all which were seeming to me to be worthy of hearing. He [Callimachus] says that Eudoxus reports that bitumen comes to the surface at certain times in the sea in the region of the Sacred Mountain in Thrace. But the sea below the Chelidoniai [Islands] has sweet-tasting springs over a large space.

The following entries (I64-6) are typical of the Callimachean geographical and geological marvels which Antigonus goes on to transmit at greater length:

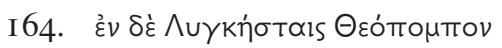

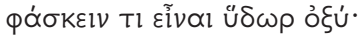
Toùs $\delta \dot{~ \varepsilon ่ K ~ T O U ́ t o u ~ T i ́ v o v T \alpha S ~}$

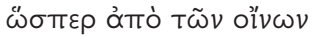

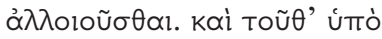

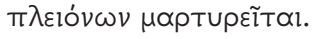

He [i.e. Callimachus] says that Theopompus says that there is a type of bitter water among the Lyncestae. And those drinking from it become confused in their minds, just as they do from wine. And this is attested by several people.

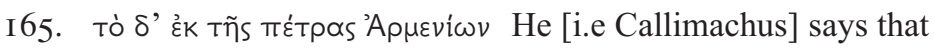

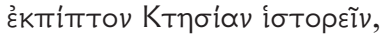

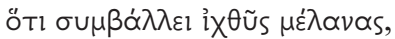

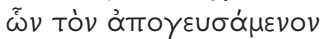
$\tau \varepsilon \lambda \varepsilon \cup \tau \tilde{\alpha} \nu$.
Ctesias reports that the water flowing out from the rock in Armenia spits out black fish which kill whoever tastes them.

Callimachus' prose work and the strong interest in both paradoxography and aetiology which it exhibits, see Krevans (2004) I73-6 and (20 I I) I 24-6.

9 For the remaining fragments and testimonia of Callimachus' paradoxographical collection, see frs. 407-I I Pf. and PGR I5-I9. 


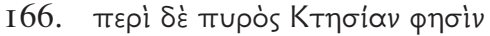

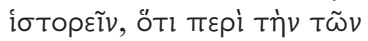

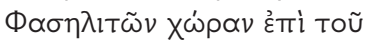

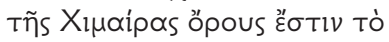

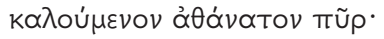

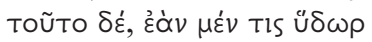

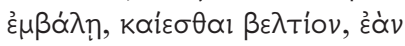
$\delta \dot{\varepsilon}$ форuTòv $\dot{\varepsilon} \pi \imath \beta \alpha \lambda \dot{\omega} v \pi \eta \dot{\xi} \xi \eta$ TIS, $\sigma \beta \varepsilon \dot{\varepsilon} v v \cup \sigma \theta \alpha$.
And concerning fire he [i.e. Callimachus] says that Ctesias reports that there is a so-called 'immortal fire' near the land of the Phaselitai on Mount Chimaera. And this fire, if someone casts water on it, burns more intensely, but if someone throws flammable material straight into it, is extinguished.

This strong interest in marvels involving water, fires and similar geological phenomena seems to have been a staple of the genre from Callimachus onwards, and is found in most of the other extant collections. ${ }^{\text {Io }}$

Other paradoxographical collections dating from the Hellenistic period include On Marvellous Things Heard (Пєрi $\theta \alpha u \mu \alpha \sigma i \omega v$

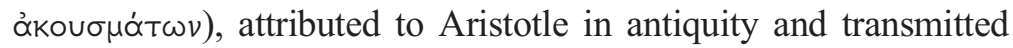
to us within the Corpus Aristotelicum, but now almost universally attributed to an unknown writer of the Peripatetic school. ${ }^{\text {I }}$ A

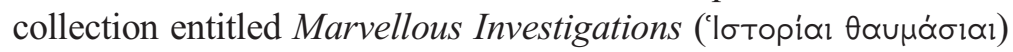
by an author known as Apollonius Paradoxographus, dated to the second century BCE, also mostly consists of accounts of geographical and zoological marvels of the natural world. ${ }^{\mathrm{I} 2}$ There is some evidence that local historians of the third century BCE specialised in paradoxographical collections focusing on local marvels. The Lesbian Myrsilus of Methymna was said to have produced a work entitled Investigations into Things Contrary to Expectation

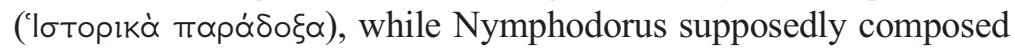

Io For good overviews of the contents of the extant paradoxographical collections, see Ziegler (I949) II37-66, Wenskus (2000) 309-I2, Giannini (I963) and (I964), Schepens and Delcroix (I996), Hansen (I996) 2-I6 and Pajón Leyra (20I I).

II The pseudo-Aristotelian On Marvellous Things Heard consists of a 'core' of thirdcentury BCE Peripatetic material which was expanded over time. On the place of the $O n$ Marvellous Things Heard within the third-century BCE paradoxographical tradition, see Flashar (1972) 50-5 and Vanotti (2007) 46-53.

12 On Apollonius Paradoxographus, see also Pajón Leyra (2014) 304-5, which notes that there is an as yet unpublished Oxyrhynchus papyrus dating from the second century CE which preserves his Marvellous Investigations 49. I. I-6. 


\section{Reading Thauma}

a geographically-circumscribed collection called Concerning the

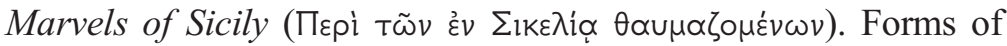
verse paradoxography also developed: as well as the aforementioned epigrams of Archelaus the Egyptian, whose work I will return to in more detail in the next section, we possess paradoxographical epigrams by Philostephanus of Cyrene, a pupil of Callimachus who seems to have built on his teacher's paradoxographical interests in a work entitled On Marvellous Rivers (Пєрi

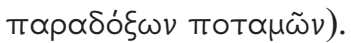

As we move into the second century BCE the production of marvel-collections continues unabated. Athenaeus claims that Polemon of Ilium, a prominent periegetic writer, wrote an $O n$ Marvels (Пвpi $\theta \alpha u \mu \alpha \sigma i \omega v)$, while the historian and geographer Agatharchides of Cnidus is said to have produced a Collection

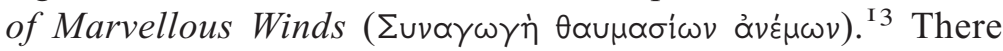
are also three extant anonymous Greek paradoxographical collections from the Roman period. The Paradoxographus Florentinus concentrates entirely on marvels connected with water, while the Paradoxographus Vaticanus (second century CE) and Paradoxographus Palatinus (third century CE) exhibit the customary mixture of natural marvels. ${ }^{\mathrm{I}}$ Another collection from the second century CE survives: the On Marvels (Пвpi $\theta \alpha u \mu \alpha \sigma i \omega v)$ by Phlegon of Tralleis, a Greek freedman of the emperor Hadrian. In terms of focus, this collection differs from its antecedents, mostly concentrating on bizarre transformations and prodigies relating to human rather than animal bodies. ${ }^{15}$ This shift towards material which focuses on marvels relating to the human rather than the animal realm is also seen in a fragmentary Oxyrhynchus papyrus (P. Oxy. II 2I8), which dates to the third century CE. It seems to preserve the remains of a paradoxographical collection by an unknown author with

13 On Polemon's interest in marvels, see Angelucci (20I4) 9-25.

${ }^{14}$ For an overview, translation and commentary of the Paradoxographus Vaticanus, see Stern (2008) 437-66.

15 On the unusual focus of Phlegon's collection, see Hansen (I996) II; on Phlegon's sources, see Shannon-Henderson (2020) I59-78. 
3.I The Emergence of the Paradoxographical Collection

descriptions of strange customs and other ethnographic details. ${ }^{\text {I }}$

Modern critical assessments concerning the reasons for the emergence of paradoxographical collections in the third century BCE have tended to focus on three essential causes: decadence, decay and distraction. ${ }^{17}$ The assumption that paradoxographical collections aim at a serious historiographical or scientific purpose which they manifestly fail to fulfil is the cause of much of the critical disappointment which this material has attracted. This disappointment is summed up by Schmid-Stählin's evaluation of paradoxography as 'ein Parasitengewächs am Baum der historischen und naturwissenschaftlichen Literatur' (a parasitical growth on the tree of historical and scientific literature) - a peculiarly botanical image which would no doubt have appealed to the natural scientific interests of the paradoxographers themselves. ${ }^{\text {I }}$ The consensus remains that the paradoxographical collection 'is to be regarded as a perverted, or misdirected product of Aristotelean research'. ${ }^{19}$ Fraser's monumental study of Alexandria under the Ptolemies goes further in explaining the apparent degeneration of a once 'pure' (i.e. properly Greek) Aristotelian scientific spirit, by linking the alleged new interest in this material to a supposed native Egyptian (i.e. eastern and decadent) love of marvellous stories. ${ }^{20}$ In addition to the irresistible lurch into the realm of the marvellous which the Egyptian land and people supposedly caused, Fraser proposes that Greeks in Alexandria were inevitably led towards an interest in paradoxography, and a concomitant and

${ }^{16} P$. Oxy. II 2 I 8 was originally published in Grenfell and Hunt (I899) 35-9; for a new edition of and commentary on this papyrus, see now Pajón Leyra (20I4) 304-30.

${ }^{17}$ For the rhetoric of 'decay' and 'decadence' which surrounds paradoxographical collections, see e.g. Giannini (I963) 248 on paradoxography as a degenerate and late development of original interest in the unknown. Cf. Wenskus (2000) 309-I2: "I9thand 2oth-cent. philologists regard the interest in mirabilia mostly as a phenomenon of decadence', and Schepens and Delcroix (1996) 378: 'time and again, paradoxography is depicted as a symptom of decay, as a degeneration of the original, healthy spirit of curiosity and inquiry that was the hallmark of Ionian culture from Homer onwards to Herodotos'.

18 Schmid-Stählin (I920-4) 237, cited at Schepens and Delcroix (I996) 378.

19 Fraser (1972a) 774. On the relationship between Aristotelian research and paradoxography, see Giannini (I963) 26I-2, Romm (I992) 92, Stramaglia (2006) 303, Stern (2008) 442, Vanotti (2007) 25-6 and Pajón Leyra (20I I) 24I-63.

${ }^{20}$ On the supposed prominence of marvels in Egyptian stories, see Fraser (I972a) 675,685 . 
unavoidable intellectual decline, through the presence of too much written material in the Alexandrian library: on this model, the presence of too many books in Egypt was catastrophic for the scientific and historiographical abilities of the ethnic Greeks, as it 'distracted their minds from speculation and historical reflection and turned them towards the collection and explanation of obscure events and phenomena'. ${ }^{2 \mathrm{I}}$ The groundless charge that the collection of thaumata represented an inexorable intellectual decline or deviation from reason prompted by contact with the Other, or a comforting escape from serious engagement with the increasing cultural complexities of the real world, is also present in more recent examinations of paradoxographical collections. ${ }^{22}$ These assumptions about the supposed lack of intellectual interest or value in this material have also led to the allegation that these collections must have been aimed at a popular audience, which is also supposedly an automatically credulous audience. ${ }^{23}$

These views, however, do not take sufficient account of the status and meaning of wonder within the Greek literary, philosophical and scientific traditions by the time that the first Hellenistic marvel-collections began to appear. In short, they do not take sufficient account of thauma itself: it is only by thinking about the place of wonder within Greek culture that the point and purpose of these texts becomes clearer. In the following three sections the reasons for the strong focus on specific types of thaumata in these texts and the complicated relationships between paradoxography and related contemporary literary discourses will be examined.

\subsection{Taming Zoological Thaumata: Archelaus the Egyptian's Peculiar Forms and the Ptolemaic Court}

Over the course of the early third century BCE, the production of textual collections of marvels took off apace in line with an increasing general emphasis on the processes of ordering knowledge which took shape together with the development of great

${ }^{21}$ Fraser (1972a) 55I.

22 See Gabba (I98I) 53 on the 'escapist' nature of paradoxography.

23 See Giannini (I963) 248, Gabba (I98I) 53, Jacob (I983) I22 and Hansen (I996) 9. 


\subsection{Archelaus the Egyptian's Peculiar Forms}

libraries in various centres of power and learning. ${ }^{24}$ The zoological and geological focus of most extant paradoxographical collections is significant when the wider ideological import of the taming and collection of actual natural thaumata under the rule of the early Hellenistic monarchs is considered. The textual collation of geological and zoological thaumata in Hellenistic paradoxographical collections represents a sort of symbolic control over the earth's most wondrous natural resources. Ptolemaic interest in natural thaumata certainly seems to have extended to the zoological as well as the geological realm. Many sources attest that the acquisition and subsequent display of exotic animals was a particular fascination of Ptolemy II Philadelphus. ${ }^{25}$ According to the second-century BCE historian Agatharchides of Cnidus (see fr. I Burstein), whose On the Erythraean Sea focuses on Ptolemaic exploration of areas around the Red Sea, Philadelphus was the first Ptolemy to pursue elephant hunting and similar exotic zoological endeavours with the aim of bringing together in one location animals which nature had separated - in other words, Philadephus was a collector of zoological thaumata.

The most famous report of Philadelphus' zoological obsessions is found in a lengthy account in Diodorus Siculus, probably derived from Agatharchides' work. Diodorus describes the king's love of hunting, collecting and displaying unusual animals in Alexandria (3.36-7), and claims that Ptolemy not only delighted in hunting and capturing elephants for the very practical purpose of waging war but even valued the acquisition of unknown beasts for the sake of widening the knowledge of 'unseen and unusually

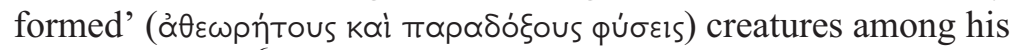
fellow Greeks. ${ }^{26}$ A group of opportunistic hunters soon realised

24 For recent appraisals of the relationship between the acquisition and collection of texts and imperial political and cultural power in ancient Greece and Rome, see e.g. Jacob (20I3a) 57-8 I, Woolf (20I3) 6-9, Johnstone (20 I4) 347-93. Cf. König and Whitmarsh (2007) 8-Io on the Hellenistic antecedents for the textualisation and ordering of knowledge in the Roman Imperial period. On the library of Alexandria and Ptolemaic power, see e.g. Erskine (I995) 38-48 and Gutzwiller (2007) I9-23.

25 See Hubbell (I935) 68-7, Rice (I983) 86-7 and Burstein (I989) 4-Io on Ptolemy Philadelphus' particular interest in collecting unusual and exotic zoological specimens.

26 Cf. also Diod. Sic. 3.I8.4 and Strabo Geography I6.4.5-7 and I7.I.5 on Ptolemaic elephant hunting. See Casson (I993) 247-60 on Ptolemy II's particular interest in the acquisition of elephants; see also Scullard (I974) I20-45 and Alonso Troncoso (20I3) 
that great rewards were at stake for capturing rare animals, and embarked on the dangerous, and eventually successful, pursuit of a

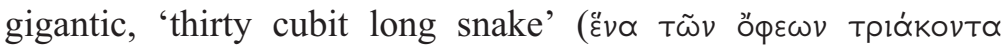
$\pi \eta \times \tilde{\omega} v){ }^{27}$ The animal was captured and tamed, Ptolemy was mightily pleased, and the snake was immediately put on display, where it soon became the 'greatest and most incredible sight for

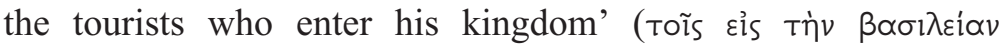

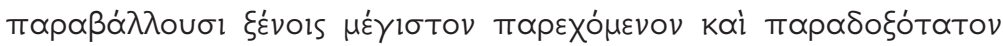
$\theta \dot{\varepsilon} \alpha \mu \alpha)$. According to the account of Hellenistic writer Callixeinus of Rhodes (c. second century BCE), which is preserved in excerpted form in Athenaeus' Deipnosophistae (I97c203 b), astonishing and unusual animals from far-off lands subject to Ptolemaic influence were among the impressive creatures displayed by Philadephus in the 270s BCE during his famous Dionysian procession through Alexandria, including 'one hundred and thirty Ethiopian sheep, three hundred sheep from Arabia and twenty from Euboia, twenty six Indian and eight Ethiopian cows, one white bear, fourteen leopards, sixteen panthers, four caracals, three panther cubs, one giraffe and one Ethiopian rhinoceros'

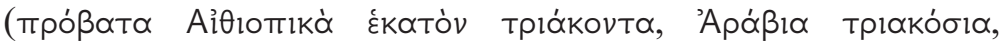

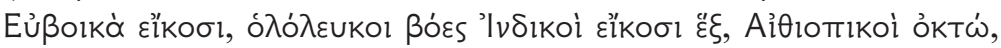

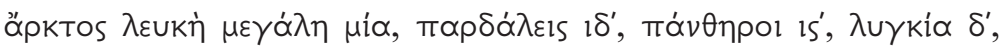

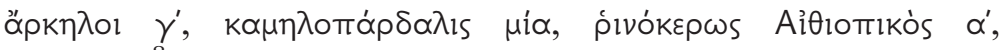
$20 \mathrm{Ib}-\mathrm{c}){ }^{28}$

It is now worth returning to the entry from Antigonus' Collection of Marvellous Investigations cited at the beginning of this chapter - Archelaus the Egyptian's epigram about the spontaneous generation of vipers from rotting human spinal marrow -

254-70 on the significance of the possession of elephants in the self-fashioning of Ptolemaic kingship in the Hellenistic period.

27 Cf. Ael. NA I 6.39, where the story of two huge Ethiopian snakes brought to Alexandria for Ptolemy Philadelphus is recounted; three large snakes were also presented to his successor Ptolemy Euergetes. There is also evidence preserved in the Zenon archive that the presentation of unusual animals to Ptolemy could play a useful political role in this period: see P. Cair. Zen. I 59075, a letter dated to 257 BCE which describes the presentation to Ptolemy of several rare wild animals and crossbreeds by a local ruler (see Edgar (I925) for the text and Hauben (I984-6) 89-93 for discussion of how the animals presented in this letter relate to Ptolemy's zoological interests).

${ }^{28}$ On the significance of this part of Ptolemy's procession and its use of Dionysus' triumphal return from India as an opportunity to display exotic animals, see Rice (I983) 82-99. 


\subsection{Archelaus the Egyptian's Peculiar Forms}

with the wider ideological import of the taming and collection of actual natural thaumata under the rule of the early Ptolemies in mind. Two fragments of similar epigrams belonging to Archelaus are cited earlier in the Collection, along with a contextual note from Antigonus which reveals that the Egyptian epigrammatist was probably attached to the Alexandrian court of either Ptolemy II Philadelphus (309-246 BCE) or Ptolemy III Euergetes (c. 284222). ${ }^{29}$ Archelaus' court context becomes clear when Antigonus introduces his poems by explicitly stating that the main purpose of the poet's production of epigrammatic thaumata was to elucidate paradoxical zoological matters for the reigning Ptolemy (Collection I9):

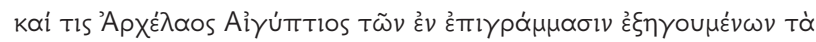

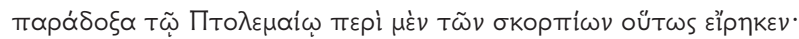

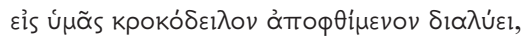

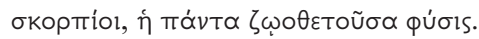

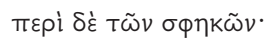

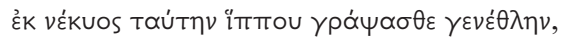

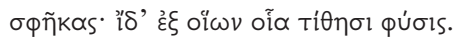

And a certain Archelaus the Egyptian, the one who explained astonishing matters to Ptolemy with his epigrams, spoke in this way concerning scorpions:

Into you Nature dissolves a putrefied crocodile,

O scorpions, Nature who makes everything alive.

And like this concerning wasps:

Make a note of this birth from the corpse of a horse: wasps!

Look! What Nature makes from such material!

The epigram about the spontaneous generation of snakes with which this chapter began, along with these poetic fragments about the generation of scorpions from dead crocodiles and wasps from dead horses, are most likely derived from an epigram

29 At $F G E$ 2I Page suggests that Archelaus' patron was either Ptolemy II or III; Berrey (20I7) 6I thinks Ptolemy III is most probable, as does Fraser (I972a) 779; Voutiras (2000) 388-9, however, suggests that Ptolemy IV Philopator may have been the monarch in question. 


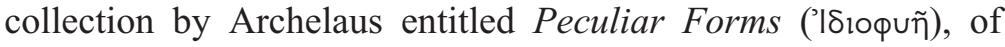
which we have other testimonia and fragments relating similar sorts of zoological marvels. ${ }^{30}$ In fact, a few other marvels described in these surviving fragments also focus specifically on examples of wondrous spontaneous generation, just as those in Antigonus' paradoxographical collection do. ${ }^{3 \mathrm{I}}$

The fragments of Archelaus' epigrams preserved in Antigonus' Collection thus provide us with a tantalising window onto what seems to have been a flourishing tradition of Ptolemaic verse paradoxography. These epigrams for Ptolemy reflect the wider ideological import of the acquiring and taming of actual natural thaumata in third-century BCE Alexandria. The presentation of such poems to the king himself (whichever Ptolemy he may have been) seems even more apt in such a context. In fact, Archelaus' verse paradoxography can be seen as a symbolic textual manifestation of a broader desire for the

${ }^{30}$ See $F G E$ 20-4 and $S H$ I 25-9 for the longer extant epigrams; cf. $P G R$ 24-8 for a comprehensive overview of all the remaining fragments. On the evidence for Archelaus' life and poetry, see FGE 20-4, Fraser (I972a) 778-9 and Berrey (2017) 6I-2. The title Peculiar Forms, the work which Archelaus seems to have been best known for, is specified at Athenaeus Deipnosophistae 409c, Diog. Laert. 2.I 7 and $\Sigma$ ad. Nic. Ther. 823. On the basis of the title Fraser (1972a) 778 asserts that the Peculiar Forms 'was probably in prose', but this was before the discovery of the Posidippus Milan Papyrus, when the use of such 'technical' titles in connection with epigrams was thought to be almost impossible. Berrey (20I7) 6I also states that Archelaus produced prose works, but there is no proof of this: all of the extant fragments of Archelaus' work are in verse. In addition to the explicit mention of epigrams in connection with Archelaus at Antigonus Collection I9, we are also told by Varro (Rust. 3.I6.4) that Archelaus wrote 'in epigrams' (Archelaus in epigrammate ait ...). It is possible that more than one collection of poems with this title was produced under the early Ptolemies. In fact, a Ptolemaic king may himself have written a poetic work entitled Peculiar Forms, though the evidence for this is debated: see FGE 84-5, SH 7 I 2, Maass (I892) 79, Fraser (I972a) 592 (alongside Fraser (I972b) 84I n. 305), (I972a) 780 and (I972b) I090, Martin (I974) Io, Voutiras (2000) 392-3 and Berrey (2017) 3I, 62.

${ }^{31}$ See also Varro, Rust. 3.I6.4 for other verses from Archelaus on the generation of bees from dead cows, wasps from dead horses and bees from dead calves. Other zoological thaumata which later ancient writers claim Archelaus wrote about include: moray eels, which have teeth similar to vipers and come up onto the land to mate with them (see $\Sigma$ ad. Nic. Ther. 823); a 'katablepas' (lit. 'downward-looking' animal), which seems to have been a bull/antelope-like creature capable of turning living beings into stone like a Gorgon (see Athenaeus Deipnosophistae 409c and cf. 22 Ib; cf. also Plin. HN 8.77 and Ael. $N H$ 7.5); a basilisk snake (see Ael. $N H$ 2.7); female partridges which conceive when they hear the voices of male partridges (see Varro, Rust. 3.2.4); goats which breathe through the ears instead of through the nostrils (see Varro, Rust. 2.3.5); and hares whose age can be determined from the number of their orifices (see Varro, Rust. 3. I2.4-5 and Plin. $H N$ 8.2 I 8). 


\subsection{Archelaus the Egyptian's Peculiar Forms}

possession, subjection and classification of natural thaumata in the Ptolemaic period. ${ }^{32}$ Although the strange biological processes which form the content of Archelaus' epigrams may seem uncontrollable and unruly, the epigrammatist's smooth and sophisticated poetic handling of these natural wonders is anything but disorderly. In fact, the epigram form, with its relative tautness of expression and general insistence on controlled and pointed diction, provides an ideal medium in which to articulate this symbolic taming of natural wonders. But the ability to arouse thauma is not confined to verse alone. As we shall see, the clipped form of the prose entries in paradoxographical collections has many similarities to the epigram form in terms of the creation of wonder through the curtailment of wider contextual framing, and both the prose and verse resources of the Hellenistic library were utilised to yield new thaumata as writers worked to reorganise and re-form knowledge itself in an effort to create impressive new bodies of purely textual marvels. ${ }^{33}$

But before turning to consider the way in which this reorganisation of knowledge was accomplished at the level of the individual paradoxographical collection, the emergence of these texts in this period must be examined in relation to two of their most influential generic antecedents: the treatment of the marvels of nature in the ethnographic writing of the past, and then the place of thauma and thaumata within the philosophical and scientific framework created by Aristotle and his Peripatetic followers.

${ }^{32}$ Cf. Schepens and Delcroix (I996) 406, who suggest that the activities of paradoxographers can be seen as a 'literary counterpart to the activities of explorers and hunters'. See also Bing (2005) I35 on Posidippus' Lithika as an expression of Ptolemaic interest in expanding cultural and scientific knowledge in conjunction with their desire for territorial expansion and control over material wealth and, more generally, Romm (I992) 84 on Greek travel narratives and ethnographic accounts of eastern lands written in the wake of Alexander's conquest as texts 'with imperial ambitions of their own, paralleling at a cognitive level the sallies of the great generals of the age'. Cf. Woolf (20II) $80-8$ on the connection between wonder and Roman imperialism in Latin ethnographic writing.

33 On the paradoxographers' dependence on the world of the library, see Schepens and Delcroix (1996) 388-9. 


\subsection{Thaumata and the Ethnographic Tradition: Herodotus and the Edges of the Earth}

As noted earlier, modern scholars have often berated the writers of paradoxographical collections for their lack of adherence to a proper sense of historiographical or scientific purpose. But to expect that a paradoxographer was attempting to produce historiography or Aristotelian science in the first place is to misunderstand the fact that this type of text has its own unique aesthetic and form. This is not, however, to say that traditions of Greek historical and scientific writing did not play influential parts in the paradoxographer's conception of his own art. In this respect the work of Herodotus in particular looms large in the background. The first half of the Histories shows the expectation that ethnographic discussions should include mention of any particular thaumata (or rather thomata, in the Ionian dialect of Herodotus' work). ${ }^{34}$ Like the marvels of the epic tradition, actual physical entities which are designated as Herodotean thomata are often visually impressive objects of astonishing magnitude or beauty. ${ }^{35}$ But it is not visual objects alone which constitute Herodotean thomata: unusual customs and traditions discovered in the course of the historian's inquiry are equally likely to be held up as marvels which simultaneously foster curiosity about other cultures while testing the boundaries of belief and credulity. ${ }^{36}$ Paradoxographical collections, which put forth a series of thaumata culled from the works of other authorities, similarly present the reader with reports which invite questions about the believability of previous traditions, although, unlike Herodotus' Histories, there is little evidence of the paradoxographer's own weighing-up of the evidence for each report, as every marvel is presented as an indisputable fact. As already noted, the focus of Hellenistic marvel-collections also remains firmly fixed on the thaumata of nature rather than

34 See Jacoby (I9I3) 33I-2, Hartog (I988) 230-I, Hunzinger (I 995) 48 n. 6 and Munson (200I) $234-42$ on the inclusion of a region's thaumata as a conventional element of ethnographic descriptions.

35 On the strongly (though not exclusively) visual emphasis of Herodotean wonder, see Hartog (I988) 230-7, Hunzinger (I995) 50-I and Priestley (2014) 58.

36 Wonder and inquiry are strongly linked in the Histories: see Munson (200I) 233-4, 259 and Priestley (2014) 70. 
those of human culture, whereas Herodotus does not make such firm distinctions. ${ }^{37}$ However, in terms of the form in which accounts of thaumata relating to distant lands and peoples are narrated in the Histories there are some very significant similarities to the way thaumata are presented in later paradoxographical collections.

For example, it has been noted that Herodotean thomata tend to provide a temporary excursion from the primary narrative of historical events in the Histories, and that multiple marvels often cluster together within the first four books of Herodotus' work. ${ }^{38}$ Rather than offering up one marvel about distant lands at a time, Herodotus presents us with multiple descriptions of increasingly bizarre thomata in a dense, almost catalogic form which perhaps reflects the supposed abundance of such strange and wondrous phenomena in exotic locations. ${ }^{39}$ This tendency is nowhere more apparent than in Herodotus' discussion of the inhabited lands at the edges of the earth (the eschatiai), in which the creation of a more extreme sense of wonder in the reader is emphasised as the narrative moves further and further out into descriptions of the world's extremities. ${ }^{40}$

It is in book 3 of the Histories that we are introduced to a prolonged discussion of the inherently wondrous nature of the world's most extreme peripheries. Herodotus begins his description with the basic contention that 'the furthest edges of the known

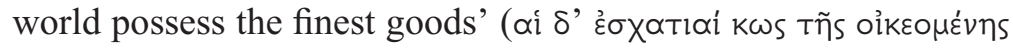

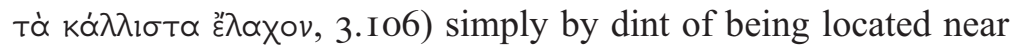
the edges of the earth. It is thus clear from the start that the geographical extremes of the known world are to be linked with

37 See Clarke (2018) I36-52 on natural and man-made marvels in Herodotus.

${ }^{38}$ On the connection between Herodotean thoma and narrative excursuses in the Histories, see Hartog (I988) 234, Gould (I989) 58 and Hunzinger (I995) 62-3.

39 See Romm (I992) 9I-3 on the tendency in the ethnographic tradition towards the creation of a catalogic effect in descriptions of marvels at the earth's edges, and the effect this has on Herodotus' presentation of thomata in the Histories.

40 See Karttunen (2002) 457-74 on the connection between thomata and the earth's edges in the Histories; cf. also Rood (2006) 297-8 and Clarke (2018) I46-9. On the increasing prevalence of encounters with the marvellous the further one travels towards the peripheries, away from the Greek 'centre' of the world, see Redfield (I985) I IO and Gould (I989) 94. Cf. also Hartog (I988) 232-3, Hunzinger (I 995) 62 n. 60 and Priestley (20I4) 58 on the increasing 'escalation' of wonder in the Histories' narrative of the eschatiai. 
extremities of description and content. Herodotus then becomes more specific and first mentions 'the region near the eastern edge

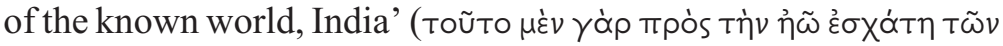

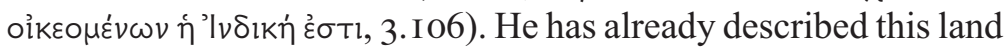
of strange geological and zoological thomata in detail in the immediately preceding sections (3.98-I05). For example, earlier in that description we were treated to the fabulous report of the extraction of gold in India involving 'ants smaller than dogs and

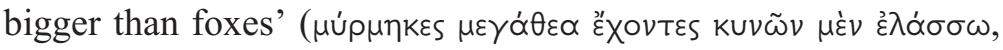
$\alpha \dot{\alpha} \lambda \omega \pi \varepsilon \dot{\varepsilon} \kappa \omega \nu \delta \dot{\varepsilon} \mu \dot{\varepsilon} \zeta \omega, 3$. IO2). The reader has thus already been primed by the earlier descriptions of marvels for the parallel and comparably wondrous collection of fine objects said to be found in the land Herodotus turns to next, 'the region near the southern

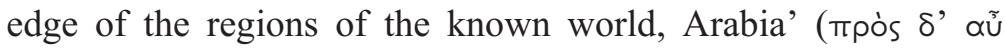

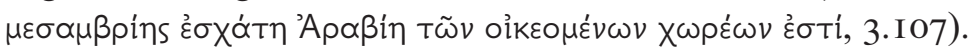

In the dense description of the marvels of Arabia which follows, Herodotus adopts a mode of description which later paradoxographical collections come to echo: a compact list of increasingly marvellous objects and customs is quickly built up to reinforce the impression that this distant land is teeming with thomata as yet unfamiliar to the Greek world. ${ }^{4 \mathrm{I}}$ Herodotus first lays out Arabia's special claim to possession of the most beautiful and wondrous objects by beginning with a description of the region's abundance in rare spices, noting that 'out of all lands this one alone produces frankincense, myrrh, cassia, cinnamon and gum mastic' ( $\dot{\varepsilon} v \delta \dot{\varepsilon}$

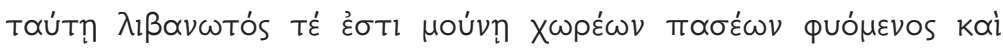

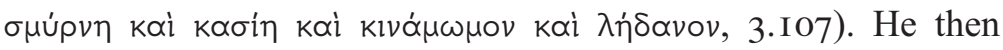
goes on to treat the collection of each of these spices in turn, with the exception of myrrh, which he claims is the only one that is easy to obtain. It becomes apparent that rather than simply listing successive fabulous stories of the collection of each spice, Herodotus is linking the transitions between each section of his excursus in a skilful and purposeful way, connecting further

${ }^{41}$ Cf. Romm (I992) 84-93 on the similar emphasis placed on abundance and diversity in Greek descriptions of the thaumata of India: this emphasis on the abundance of the biological forms found in such places increases the sense that the lands at the edges of the earth are unruly and disorganised and therefore in need of 'conquering' by the Greeks in order to tame their strangeness.

60 
relevant discussion of the wondrous nature of Arabia's zoology to his wider description of spice collection in order to present a forceful image of this region's abundance in every sort of marvel belonging to the natural world. The effect of these complex transitions is crucial in creating the escalating sense of wonder which binds the description of Arabia to the historian's wider argument about the earth's extremities. ${ }^{42}$

This becomes clearer when we examine each method of spice collection. The first spice to be gathered is frankincense (3.107). The action begins when storax, a fragrant tree resin, is burnt to ward off the 'winged snakes, small in size and multicoloured in

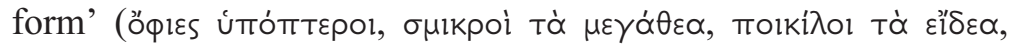
3.I07) which guard the frankincense: this then allows the spice to be collected safely. In passing, Herodotus notes that these winged snakes are 'the ones which attack Egypt' (oưtor oi $\pi \varepsilon \rho$

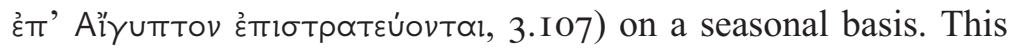
links back to an earlier moment in the Histories' Egyptian logos (2.75), where Herodotus makes a controversial autoptic claim concerning these same Arabian snakes:

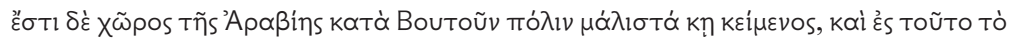

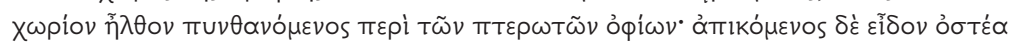

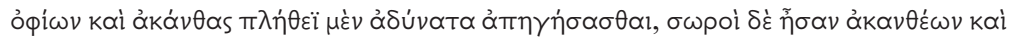

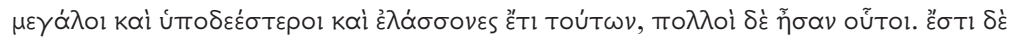

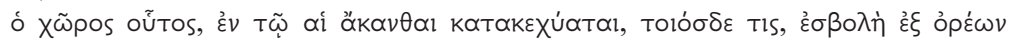

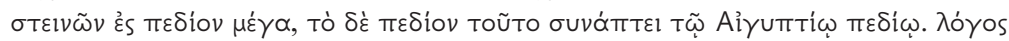

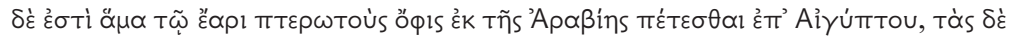

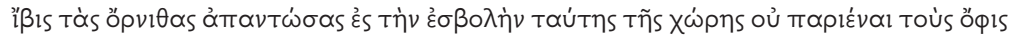

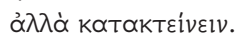

There is a place in Arabia very near the city of Buto, and I went to this region to learn about the winged snakes. When I arrived there I saw a huge number of bones and backbones of snakes, impossible to describe in full: there were heaps of backbones, some large, some smaller, and some smaller still: and these were very many. And this place where the backbones lie, is something like this: a pass out of the narrows of the mountains into a broad plain, and this plain joins with the plain of Egypt. It is said that at the start of spring winged snakes fly from Arabia towards Egypt, but the ibis birds meet them in the mountain pass and not only do they prevent the entry of the winged snakes, they kill them.

42 See Pelling (2000a) I 72 on the 'host of careful transitions' in book 2 of the Histories: Herodotus makes use of a similar method here. 
The second mention in book 3 of these marvellous flying snakes thus adds to the sense that we are moving towards an increasingly wondrous sphere, as the narrative moves geographically to the southernmost limit of the world. If - Herodotus almost seems to say to us - the mere remains of these dead winged Arabian snakes caused me to stop and wonder in Egypt, that 'land more full of

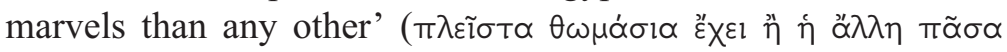
$\chi \omega \dot{\rho \eta}, 2.35$ ), then how much more marvellous is Arabia, home to trees full of live winged snakes? Arabia here becomes the producer and point of origin of one of Egypt's most bizarre zoological wonders, and the overall point is clear: the further out from the Hellenic centre of the world one travels, the more marvellous the natural phenomena one witnesses or hears about are likely to be.

The tendency of thoma to provide opportunities for continued, rolling excursuses is also manifested in Herodotus' mention of these creatures within his broader description of Arabia's rare and wondrous spices, for the reappearance of the winged snakes now provides him with the opportunity to transition smoothly into an impressive display of Ionian scientific thinking as the historian suddenly embarks upon a complex discussion of several important principles underpinning the broader biological balance of relative numbers of predators and prey in the animal world. In relation to the winged snakes in particular he tells us that, according to the Arabians, such is the ferociousness and mobility of these creatures that, if nature failed to intervene and instead left their reproduction unchecked, 'the entire land would be filled up with these snakes'

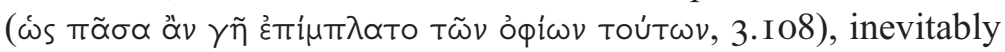
leading to the presence of too many of the fearsome predators in the world as a whole. But as it is the proportion of predators and prey remains balanced because of the fact that the female winged snake kills the male during mating and is in turn then killed when 'her young, exacting vengeance for their father, gnaw through

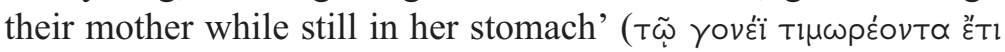

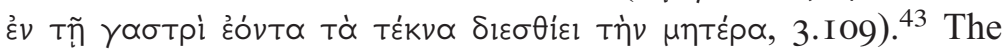

43 On this passage, see Thomas (2000) I39-50. On account of the zoological focus of Herodotus' discussion at 3.I08-9 his reports of two further wondrous examples of unusual and violent animal parturition in this passage - the first involving the reproduction of vipers, the second about lionesses and the birth of lion cubs - are among the very 
theoretical and scientific nature of this discussion about the reproductive peculiarities of winged snakes and other, more conventional predators only serves to make the zoology of Arabia seem both simultaneously familiar and strange, as well as giving an impression of scientific accuracy and authority far removed from the increasingly fabulous descriptions about to come.

After this zoological meditation Herodotus moves swiftly back to the theme of Arabian spice collection, shifting from winged snakes to other unconventional 'winged creatures, very much like

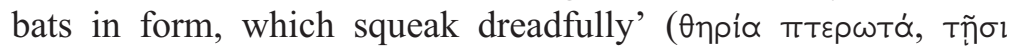

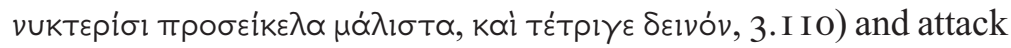
men bound in protective ox-hides as they collect the spice cassia. The vague description of the winged animal is important because there is a gradual movement in this section from the winged snake - a creature which is definitely not a bird but nevertheless happens to have wings - to this bat-like creature, which has more in common with a true bird than a winged snake, but still does not seem to be a bird proper. The reason why Herodotus focuses above all else on the winged nature of this ambiguous bird-like creature becomes clear when we reach the description of the next method of obtaining an exotic Arabian spice: the collection of cinnamon with the help of giant birds. ${ }^{44}$ Wings are once more at the forefront of our attention, as Herodotus describes in detail (3. I I ) how the giant Arabian birds first carry the cinnamon off to nests which men cannot reach. These birds are soon lured back down to the ground by men who placed dead oxen, asses and beasts of burden below the nests. After flying down the birds collect these offerings and carry them back to the cinnamon-filled nests, which cannot bear the extra weight and fall down, cinnamon in tow. This method of spice-collection is even explicitly marked as an event which is 'even more wondrous than the previous methods' ('ُ $\theta \omega \mu \alpha \sigma \tau o ́ t \varepsilon p o v, 3$. I I I), highlighting Herodotus' concern to create

few thaumata that are explicitly cited from his work in later paradoxographical collections: see Antigonus Collection 2I on both the lioness and the viper and Ps-Arist. Mir. ausc. 165 on the viper.

44 Detienne (I994) I4-20 emphasises the contrasts and similarities between the collection of cassia and cinnamon through the use of specifically bird-like animals, but does not focus on the use of winged creatures as a means of transitioning from marvel to marvel in the Arabian excursus as a whole. 
an ongoing escalation of wonder in his narrative of the earth's edges.

This sense of escalating wonder is further reinforced when the collection and production of the next spice, a fragrant gum called ledanon, is once more explicitly marked as 'even more

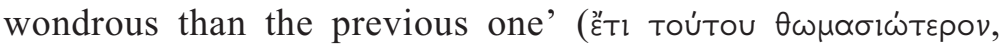
3.II2). Unlike the previous methods of spice-collection, the gathering of Arabian ledanon does not involve a wondrous winged creature: the substance is instead 'found in the beards

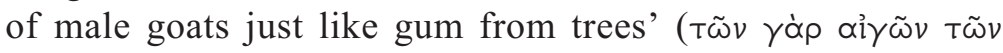

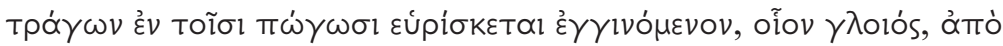
T⿰氵 $u^{u} \lambda \eta s$, 3.II2). At first this sudden movement away from wondrous winged creatures might strike the reader as rather arbitrary, but the placement of this specific method of collection at the very end of Herodotus' catalogue of spicy Arabian marvels is actually an important point of transition into the next segment of the broader Arabian excursus. ${ }^{45}$ This is because fragrant-gum-producing goats span across (and can be included within) the two very specific - and very diverse - categories of Arabian thaumata found in Herodotus' ethnographic catalogue of marvels: marvellous spices and wondrous caprids. The significance of this skilful placement of this specific marvel at this precise moment in the catalogue becomes even clearer when we examine how this choice permits the seamless narrative shift from spice-bearing goats to two astonishing kinds of sheep (3.II3):

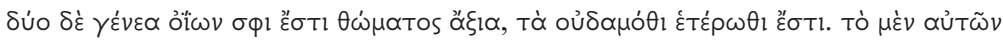

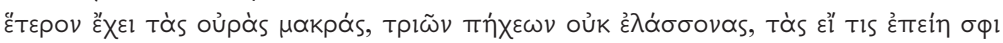

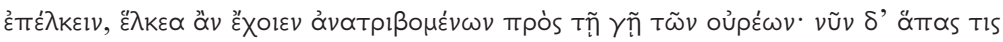

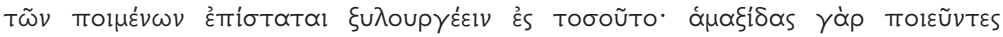

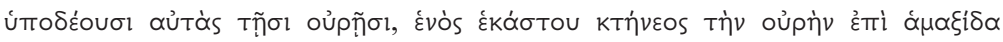

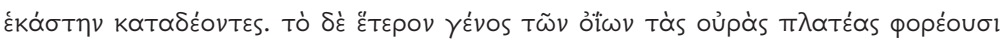

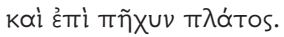

They have two kinds of sheep worthy of wonder which are found nowhere else. One type has a long tail, no less than three cubits long. If one were to allow them to drag these tails, they would wound themselves through rubbing them on the

45 These wondrous cinnamon birds also turn up as a thauma at Antigonus Collection 43, an entry which cites Aristotle's discussion of these strange creatures at Hist. an. 6I6a6-I2. 


\subsection{Thaumata and the Ethnographic Tradition}

ground. But instead every shepherd there knows at least this much carpentry: enough to make little carts which they tie under the tail, binding each sheep's tail to its own cart. The other kind of sheep has a tail a full cubit broad.

With these final examples of Arabia's natural marvels Herodotus' excursus on the southernmost limit of the world ends. Subsequent brief surveys of the world's westernmost limits in Ethiopia (3. I I4) and northernmost limits in the land of the Arimaspians (3. I I6) are then followed by Herodotus' final conclusion that 'the edges of the earth possess those things which seem to be finest and rarest' (T⿺辶

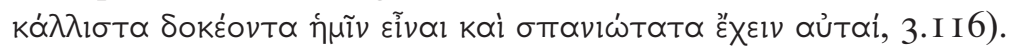
With this statement - a very clear echo and ring composition of Herodotus' opening declaration that 'the furthest edges of the

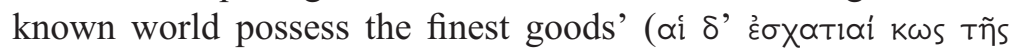

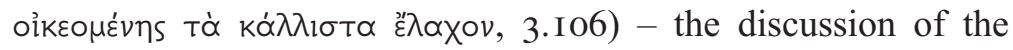
nature of the inherently wondrous properties of the earth's edges concludes.

The collection of multiple marvels narrated in a dense, almost catalogue-like style and connected through oblique transitional motifs which we find in Herodotus' Arabian excursus is a literary form echoed in the structure of later paradoxographical collections. In these texts the connections between entries are also often not as arbitrary as they may at first appear. ${ }^{46}$ On closer inspection, most paradoxographical collections can be seen to link thaumata together in loose thematic clusters which enable the reader to consider the possible relationships between each marvel. ${ }^{47}$ Moreover, when entries are viewed in relation to one another, and within the wider context of the work as a

${ }^{46}$ Priestley (2014) 84 notes that paradoxographical works bear some resemblance in their structure to Herodotus' marvel-passages, but I would go much further and suggest that the effect upon the reader shows similarities in both cases, as does the use of complex transitional techniques. Cf. Romm (I992) 9I for the suggestion that the catalogic effect of listing ethnographic thaumata was a key aspect of Ctesias' writings on distant lands, though the fragmentary nature of his extant work makes it difficult to ascertain fully how this effect was created in practice. Nichols' suggestion (2018: $3^{-16}$ ) that Ctesias' Indica, with its inclusion of many marvels and focus on a single geographical area, can be seen as a 'bridge' between fifth-century BCE historiography and third-century paradoxographical collections is certainly compelling, though the fragmentary state of the Indica once again makes detailed comparison difficult.

47 Jacob (I983) I28, Hansen (I996) 4-5 and Krevans (20II) I25 have recognised the importance of thematically connected sequences of thaumata within Antigonus' paradoxographical collection. 
whole, it is usually possible to discern more complicated principles of arrangement, whereby certain keywords are used to create implicit and explicit links which allow skilful transitions between entries.

A fresh example, a sequence of zoological thaumata, taken this time from the pseudo-Aristotelian On Marvellous Things Heard, demonstrates these principles of loose thematic ordering and shows how one of the aims of the paradoxographical collection is to allow new and unexpected connections to be drawn between previously disparate thaumata (9-I2):

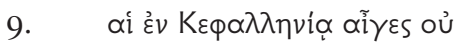

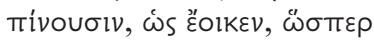

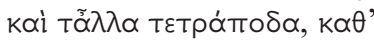

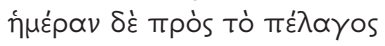

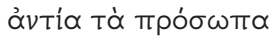

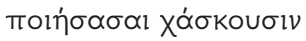

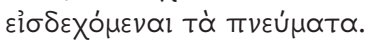

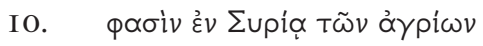

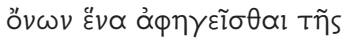

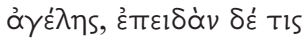

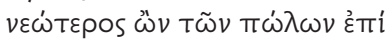

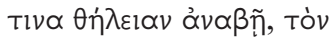

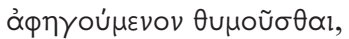

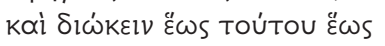

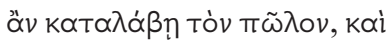

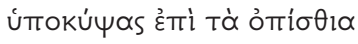

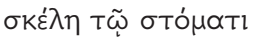

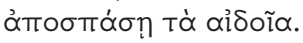

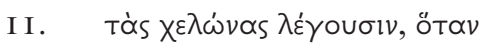

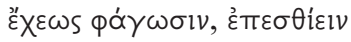

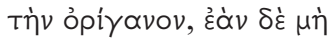

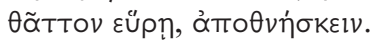

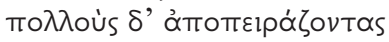

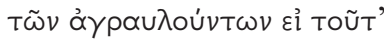

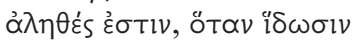

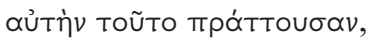

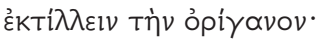

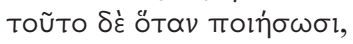

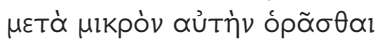

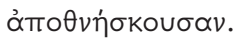

The goats in Cephallenia do not drink, it seems, as other quadrupeds do. Instead, every day, after turning their faces towards the sea, they open their mouths wide and take in the air.

They say that in Syria one wild ass within the herd is the leader. And whenever one of the younger ones mounts a female, the leader of the herd becomes angry, and he chases the young ass until he catches him, and stooping under his hind legs he tears off his genitals with his mouth.

They say that tortoises, whenever they eat vipers, eat wild marjoram afterwards, and if they do not find any quickly, they die. And many rural people, making trial of this to see whether it is true, pull up wild marjoram whenever they see a tortoise, and whenever they do this they see the tortoise die within a short space of time. 


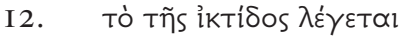

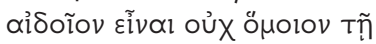

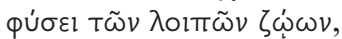

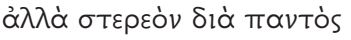

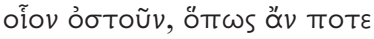

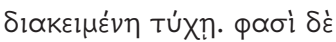

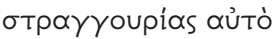

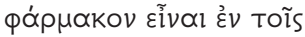

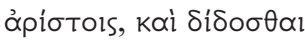

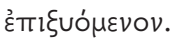

It is said that the penis of the marten is not like that of other animals. Instead it is hard at all times, like a bone, no matter what the circumstances are. And they say that the penis of the marten is the best remedy for strangury and is given in powdered form.

In the above examples several key themes are reiterated in different ways, in order to bind together the otherwise disparate entries. The unexpectedly airy diet of goats in Cephallenia is most obviously paralleled by the tortoise's strange dietary habit of washing down vipers with marjoram. In between these entries concerning odd zoological eating habits, we are told about the propensity of the angry adult ass to castrate his younger rivals. The sudden intrusion of genitalia is echoed by the focus on the marten's endless erection, which comes after we are told of the tortoise's dietary requirements. At the most obvious level there is an alternating arrangement of theme here. But on another level all four of these marvels can be linked together under an alternate heading of 'unexpected things animals put in their mouths': goats gape with their mouths open to drink the sea air, an ass tears off genitals 'with his mouth' ( $\tau \tilde{\omega}$ $\sigma \tau o ́ \mu \alpha \tau \imath)$ specifically, tortoises can only put snakes into their mouths if they are well-seasoned, and even humans occasionally take in powdered marten penis (presumably orally?) when suffering from strangury. ${ }^{48}$

${ }^{48}$ Similar connections spread out and ripple through the other entries in the initial section (entries I-30) of zoological marvels in Ps. Arist. On Marvellous Things Heard. Just before we reach the examples discussed here, we are told in entry 4 that goats seek out a certain herb when injured (cf. the tortoise needing wild marjoram); birds eat things from the mouths of crocodiles in entry 7 (cf. the unexpected eating habits on display in 9-I2); hedgehogs can tell which way the wind is blowing and change direction as a result in entry 8 (cf. goats turning their faces to the air in entry 9); after entries 9-I2 (cited in full above), we return to the eating habits of birds in entry I3, which tells us that woodpeckers peck so far into trees in search of food that the trees collapse (cf. birds and food in entry 7 , and the following description of another bird eating in entry I4: pelicans swallow mussels and then vomit up the shells). 
When viewed in this way, the careful transitions and connections between entries echo those in Herodotus' descriptions of ethnographic thomata, as well as being reminiscent of some of the ordering principles discerned in later miscellanistic texts. In these, a 'latching-on' technique allows seemingly disparate material to hang together, as one bizarre subject somehow tumbles effortlessly into another. ${ }^{49}$ This sense of one marvel tumbling into another is essential to the aesthetic of paradoxography as a whole: the ability of texts to communicate back and forth in unexpected dialogue with one another is key to the creation of surprising continuities and discontinuities which arouse the bafflement and wonder that the paradoxographical collection is aiming for. This effect is further reinforced by the paradoxographer's methods of excerpting his source texts, as the next section will demonstrate.

\subsection{Reactivating Thauma: Paradoxography and the Aristotelian Tradition}

The ethnographic tradition is not the only mode of writing from which paradoxography draws. As mentioned earlier in Section 3. I, the strong connection between the traditions of Peripatetic philosophy and science and the work of the Hellenistic paradoxographers has often been noted, especially in respect of the themes and content of their works. But the significance of the place of thauma within Aristotle's conceptual framework of philosophy and science as a whole on the paradoxographers' conception of

49 See Pelling (2000a) I7I-90 on this 'latching-on' technique and the sophisticated principles of arrangement in Athenaeus' Deipnosophistae. In terms of this 'latchingon' technique in particular, the paradoxographical collection should be seen as an important precursor of later 'miscellanistic' styles of writing, which often reveal the presence of complex structures on closer examination of the author's presentation of material. For recent reassessments of the complicated structural strategies adopted in miscellanistic texts, often in the face of implicit or explicit authorial denials of such ordering, see e.g. König (2007) 43-68, Klotz and Oikonomopoulou (20II) 22-7 and Morgan (20I I) 70-3 on the miscellanistic quality and ordering principles of Plutarch's Quaest. conv:; Vardi (2004) I69-86 and Howley (2018) on Gellius' NA; Smith (20I4) 47-66 on Aelian's NA; Wilkins (2000) 23-37, Jacob (2000) 85-I IO and Jacob (20 I3b) on Athenaeus' Deipnosophistae. See also König and Whitmarsh (2007) 3I-4 on strategies for ordering disorderly miscellanistic knowledge in Imperial prose more generally. 


\subsection{Paradoxography and the Aristotelian Tradition}

their texts has not yet been examined fully. The most explicit and significant Aristotelian discussion of the place and purpose of thauma in philosophy comes in the passage from the opening of the Metaphysics (982bI2-2 I) which has already been mentioned at the very beginning of this book, now cited here at greater length:

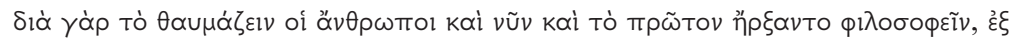

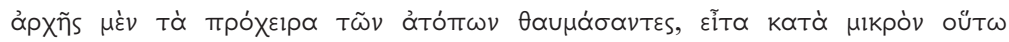

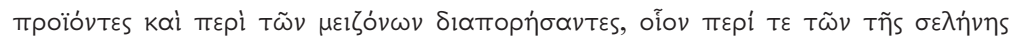

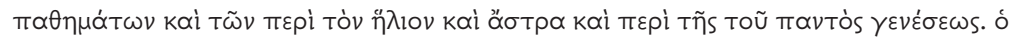

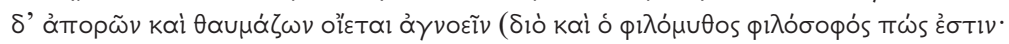

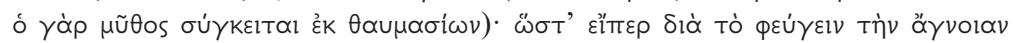

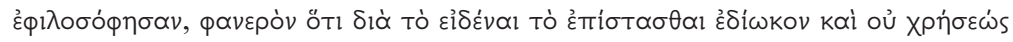

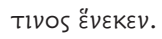

Through wonder men now begin, and once first began, to philosophise: from the beginning they have wondered at strange things which were near at hand, and then progressed forward step-by-step in this way, raising questions about greater matters, such as the changes of the moon and the sun and the constellations and the origin of everything. And the man who is perplexed and who wonders feels that he is ignorant (and for this reason the lover of myth is in some way a philosopher, for myth is composed of wonders). As a result, if it was to escape ignorance that men philosophised, it is clear that they pursued understanding for the sake of knowing, rather than for some practical use.

For Aristotle, thauma is thus able to motivate the pursuit of knowledge itself by encouraging the recognition of one's own ignorance concerning the object, matter or phenomenon which is the cause of such wonder. ${ }^{50}$ Wonder acts as a sort of protreptic to philosophy and the attainment of knowledge: a spur to curiosity which is initially useful, but is to be discarded and replaced by knowledge once the causes of a given phenomenon have been understood. Philosophy therefore stems from thauma, and it is possible to wonder at and philosophise concerning matters both big and small (in size and significance), near and far.

Aristotle makes this point again in a slightly different way in his De partibus animalium (645aI 5-I7), where he issues a protreptic

$5^{\circ}$ The relationship between thauma, recognition, ignorance and knowledge in Aristotle's work will be discussed again in greater detail in Chapter 5, Section I. On thauma and thaumata in Metaphysics, see e.g. Schaeffer (I999) 64I-56, Cambiano (2012) 34, Broadie (20I2) 62-7 and Bowe (2017) 50-72. 
towards the study of animal bodies by arguing that it is easier for us to begin inquiring and gaining knowledge of creatures which are familiar and accessible to us, before turning to weightier matters concerning the heavens, which are much further away and therefore more difficult to contemplate and understand fully. For this reason, 'the study of even the lowest animals' (тทे $\pi \varepsilon \rho i$

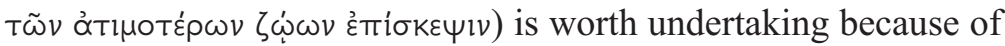
the fact that 'there is something wondrous in every aspect of the

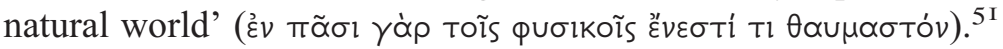
For Aristotle, the thauma generated by the contemplation of even the smallest biological problem affords the chance to philosophise and ultimately, in due course, to move towards the understanding of greater and more impressive phenomena.

There are indications that this Aristotelian conception of thauma as a crucial starting point for further inquiry lies in the background of the production of Hellenistic paradoxographical collections. In this regard it is particularly striking that the connection between thauma and inquiry seems to have influenced Callimachus, the first named producer of a marvel collection of whom we are aware. To judge from the surviving fragments of his Collection of Marvels from Every Land Arranged According to Places, Callimachus' marvel-collection focused primarily upon geological and geographical thaumata, especially wondrous bodies of water. But his paradoxographical collection is not the only work to exhibit such an interest in unique geographical features in particular locations: his Aitia also deals with such features in connection with cultural and historical particularities. ${ }^{52}$ This sense of a connection between Callimachus' interest in paradoxography and aetiology is further strengthened if we turn to the Aitia itself and note the role which wonder plays at a crucial

5I See Lennox (200I) I72, Nightingale (2004) 262-5, Poulakos and Crick (20I2) 30I-4, Thein (2014) 2I7-I8 and Tipton (20I4) 68-9 on the place of wonder within Aristotle's defence of and protreptic towards the study of lower animals. See Balme (I972) I 22-4 on the unusual nature of this passage in the De partibus animalium.

52 See Prioux (2009) I2 I on the parallelism between the Aitia and Callimachus' paradoxographical collection in terms of the pronounced interest which both works exhibit in the geography (especially rivers) of the West (especially Magna Graecia). The continuities between Callimachus' interest in aetiology and paradoxography have also been noted by Fraser (I972a) 774, Krevans (2004) I73, and Acosta-Hughes and Stephens (2012) I7. 


\subsection{Paradoxography and the Aristotelian Tradition}

transitional point between two discussions of cultic practices in book 2 of the poem. In the first aition (fr. 43-43a Harder) of this book, Callimachus, apparently conversing with and questioning the Muses, exhibits his own scholarly knowledge by providing a catalogue of Sicilian cities before Clio answers the poet's question about the foundation cult of Zancle. The transition into the next aition then begins (fr. 43b I-4 Harder):

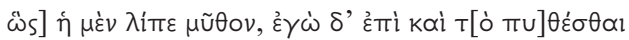

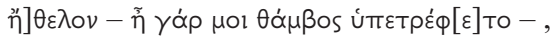

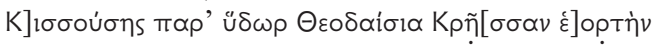

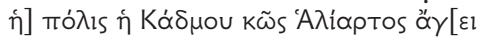

In this way she ended her account, but I was full of desire to learn this as well - for truly my wonder was nourished - why near the waters of Kissousa does the city of Cadmus, Haliartus, celebrate the Theodaisia, a Cretan festival ...

The poet's astonishment at Zancle's cult, and Clio's explanation of its provenance, here fuels a further desire for aetiological answers, this time in connection with a seemingly unrelated question concerning the reasons why the Theodaisia is celebrated both on Crete and at Haliartus in Boeotia. Crucially, it is wonder which here feeds the scholarpoet's child-like curiosity, and becomes the starting point for renewed inquiry, as well as being the impulse which encourages the transition from one aition to the next. ${ }^{53}$ Like Aristotle's philosophical inquiries, Callimachus' aetiological questions find their starting point in wonder, and the contemplation of one small point of cultural interest has the potential to nurture a pursuit of knowledge concerning what may at first seem radically separate matters. ${ }^{54}$

53 On thambos as a response to Clio's answer to Callimachus' obscure question, see Hutchinson (I988) 44. Cf. Fantuzzi and Hunter (2004) 59 on the use of wonder to link the Haliartus episode to the seemingly unrelated discussion of Sicilian cities which precedes it; see also Harder (2012) 303 and 362 on thambos as a transitional device which reveals 'how Callimachus pretended that amazement and curiosity were the impulses that accounted for his choice of subjects'. Cf. Cozzoli (20I I) 424-7 on the significance of thambos in fr. 43a Harder, and on the narrator's pose of child-like curiosity and wonder in the Aitia as a whole. On the general significance in the poem of the child-like posturing of the Aitia's narrator, see Snell (I953) 27I-6.

54 See Fantuzzi and Hunter (2004) 59-60 on the similarity between Callimachus' inquiries and the Platonic/Aristotelian notion that philosophical inquiry originates in wonder. 
There is, however, an additional complication when it comes to nurturing the reader's curiosity about those very problems of Aristotelian inquiry that the paradoxographical collections tend to focus on, which is precisely that the works of Aristotle and his Peripatetic followers had already provided a readymade explanatory framework in which to contextualise many natural thaumata. This had the potentially disastrous effect of curtailing the budding philosopher's ability to start with small and unexplained natural marvels near at hand, before moving on to weightier matters of philosophy. Due to the assiduous scientific and philosophical work of scientific thinkers from the Ionian school down to Aristotle, certain natural thaumata had perhaps already become too familiar. A process of defamiliarisation was therefore necessary before nature might seem sufficiently strange again. This is precisely what the paradoxographical collection offers to the reader. Rather than building up and explaining the causes and context behind a given phenomenon in order to nurture a desire for further knowledge - a process which we see enacted somewhat comically in Callimachus' Aitia - the writer of paradoxography adopts an almost diametrically opposed strategy in order to achieve the same effect. Phenomena which are already relatively well-contextualised and explained are stripped back, pared of their explanatory framework, and made to astonish again.

With this in mind, the seemingly puzzling methods which the paradoxographer adopts with respect to his source texts begin to make more sense. Luckily for us, some of the source texts which lurk in the background of certain sections of some extant paradoxographical collections survive, allowing us to examine the intricacies of the paradoxographer's excerpting art in closer detail. Perhaps the most fascinating example is a large central section of Antigonus' Collection of Marvellous Investigations (26-I I5) which makes extensive use of Aristotle's Historia animalium, and permits us a close-up view of paradoxography's relationship to Aristotelian biology. This is because many of the thaumata which Antigonus culls and adapts from the Historia animalium are part of much longer zoological discussions in 
which Aristotle has contextualised, classified and often at least partially explained the biological phenomena which he is documenting. In almost every case in Antigonus' Collection, however, the paradoxographer neglects to adapt any of this wider contextual padding in his own work. ${ }^{55}$

In fact, Antigonus actually emphasises that the removal of Aristotle's explanations of the causes of phenomena relating to the animal world is an integral aspect of his own paradoxographical art in a brief authorial comment in his text, a rare moment where he explicitly discusses his principles of selection and composition. After relating a marvel excerpted from the Historia animalium Antigonus notes (Collection 60) that Aristotle 'took

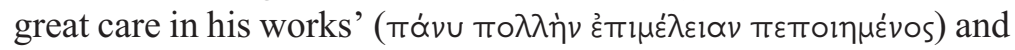
explained things 'without including extraneous information in his

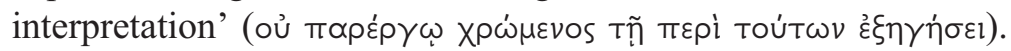
He also comments that Aristotle 'wrote almost seventy books about animals and endeavoured to focus more on explaining matters rather than narrating them in each of these works' (T $\dot{\alpha}$

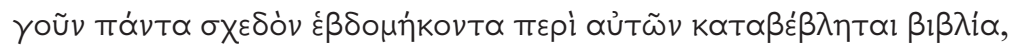

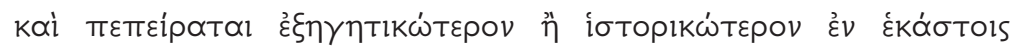

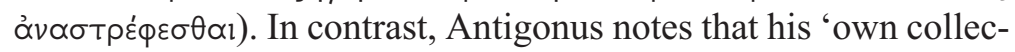
tion focuses only on the selection of strange and incredible content from these Aristotelian works and passes up on other types of

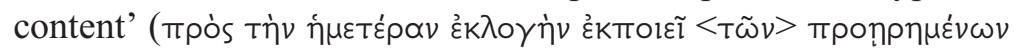

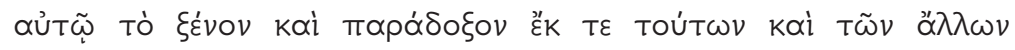
$\varepsilon \dot{\pi} 1 \delta \rho \alpha \mu \varepsilon \tilde{v})$. As this explicit comment makes clear, Antigonus' primary aim within his marvel-collection is the evocation of a sense of the strange and incredible through the deliberate curtailment of Aristotelian explanation.

55 I am grateful to one of the anonymous readers for drawing my attention to the fact that this stripping of contextual padding is somewhat aided by Antigonus' choice to use the Historia animalium as his source text, rather than any of Aristotle's other biological works, because the focus of that text is mostly on the classification, collection and grouping of animals rather than on large-scale causal explanation. The paradoxographer's task of finding wondrous material buried within Aristotle's wider contextualised discussion is therefore made easier by the variety of the phenomena recorded and classified in the first place. For summaries of various positions relating to the distinctiveness of the aim, focus and purpose of the Historia animalium in Aristotle's biological corpus, see Gotthelf (20I2) 26I-92, 309-24. 
The deliberate effects of Antigonus' striving for the strange through this method of excerption and adaptation can be seen more clearly if we examine some of his thaumata alongside Aristotle's original discussions in the Historia animalium. The three short successive marvels which form the seventy-third to seventy-fifth entries in Antigonus' collection are good examples of the paradoxographer's typical treatment of his source texts:

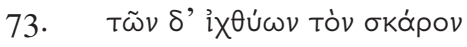

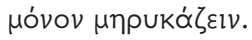

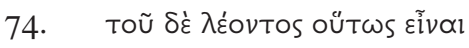

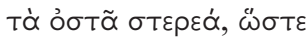

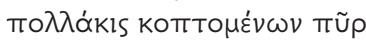

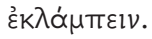

75.

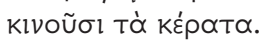

[And Aristotle says that] the parrotfish is the only fish which chews the cud.

[And Aristotle says that] the bones of the lion are so hard that often fire flashes forth from them when they are struck.

[And Aristotle says that] there are oxen in Phrygia which wiggle their horns.

When stated in this bare form these enigmatic and puzzling statements encourage the reader to marvel at the peculiarities of the natural world, while simultaneously testing the boundaries of credulity. Do we really believe that a trip to Phrygia could result in an encounter with cow horns of a type we have never experienced before, or are we to doubt the veracity of this claim despite the fact that Aristotle himself supposedly said it?

In fact, Aristotle really did say all of these things, as well as all the other claims attributed to him in Antigonus' paradoxographical collection. If, however, we turn to Aristotle's biological works we find that the paradoxographer has always been very careful to cherry-pick his thaumata out of the vast zoological discussion in a way which distorts their original meaning. Two mutually reinforcing strategies are employed to achieve this goal. The paradoxographer either selects the unusual exceptions to various biological rules which Aristotle lays out carefully in the first place, or he strips away the complicated reasoning which the philosopher builds up to explain away an apparent inconsistency or anomaly. The cud-chewing parrotfish is a good example of the combination of these two methods. In Antigonus' Collection the creature's 


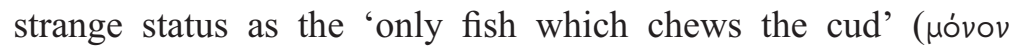

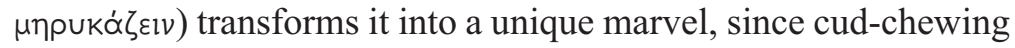
is naturally associated with large land animals such as cows rather than fish. None of Aristotle's reasoning or carefully collected contextual information about the parrotfish's digestive system is preserved: only the bare fact of this creature's seemingly strange behaviour remains.

However, if we turn to the precise mention of the cud-chewing parrotfish in the Historia animalium (508bIo-I2) and examine its wider context, we quickly see how crucial Antigonus' careful curtailment of Aristotle's wider reasoning is to the creation of a sense of wonder in his marvel-collection. In Aristotle's text the fish's unusual masticatory habit is mentioned in a long discussion about different types of animal stomach. This wider discussion makes clear why Aristotle sees fit to mention the parrotfish's strange status here, since one element which he consistently comments on in this work in relation to the form of an animal's stomach and digestive processes is its dentition. At 507a34-6 Aristotle declares a general rule that 'horned viviparous quadrupeds which do not have teeth in both jaws possess four-chambered stomachs: these are the animals said to "chew the cud" ( $\tau \tilde{\omega} v$

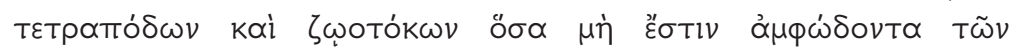

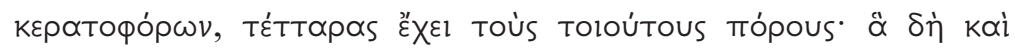

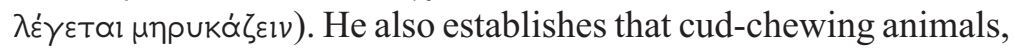
having teeth in only one jaw, do not have straight guts since 'animals without teeth in both jaws do not possess a straight gut'

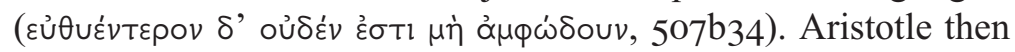
moves on to the assessment and classification of the digestive systems of oviparous animals, starting with snakes and then moving onto fish, which he declares 'have one simple stomach' ( $\mu$ i $\alpha v$

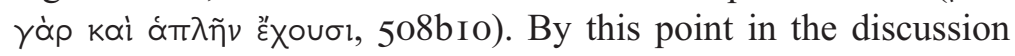
Aristotle has thus established that all cud-chewing animals have four-chambered stomachs, non-straight guts and teeth in only one jaw, while all fish possess only one stomach.

It is at this point that the parrotfish, the 'only fish which seems to

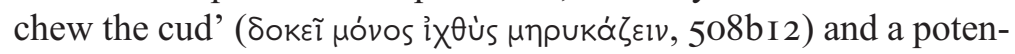
tial outlier in the careful taxonomy of stomachs which has just been laid out, is mentioned. According to Aristotle's system, if the 
parrotfish really did chew the cud it would possess a four-chambered stomach, only one jaw full of teeth, and a non-straight gut. The issue is quickly settled when it is revealed that, despite its apparent cud-chewing capabilities, the parrotfish possesses a sin-

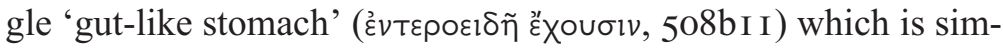

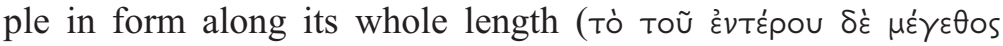

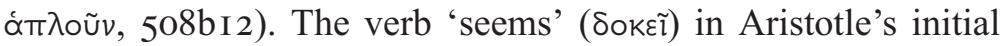
statement about the animal's apparent cud-chewing thus takes on its full force here, since on closer inspection it turns out that the parrotfish, with its singly-formed gut-like stomach, must be a fish after all - even if the action of scraping at coral with its beak-like protrusion does make the creature look as if it is chewing the cud when eating. ${ }^{56}$ But all of these complexities are very deliberately elided in Antigonus' Collection. According to the paradoxographer's account, Aristotle does not say that the parrotfish seems to eat in this way, he simply asserts that 'the parrotfish is the only fish

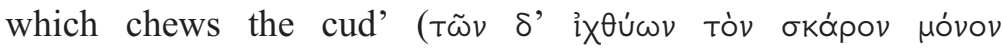

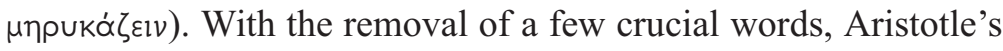
careful and informative discussion of fish stomachs is obliterated, and in its place a baffling thauma arises.

A similar paradoxographical manoeuvre takes place when it comes to the pyrotechnical potential of lion bones. In the Historia animalium the unusual qualities of the bones of the lion receive a special mention during a much longer discussion on the nature of animal bones when Aristotle notes that 'the lion possesses bones which are harder than those of any animal; they are so hard that fire flashes out of them when they are rubbed together,

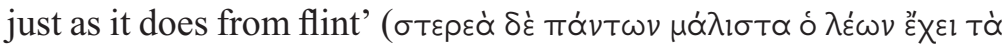

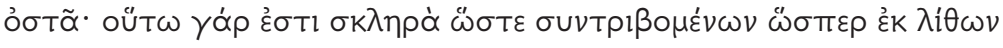

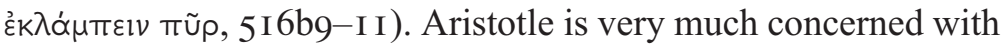
the relative hardness of animal bones in this part of his discussion, rather than their inherent flame-producing potential, but from Antigonus' truncated and context-free adaptation of this wider

${ }^{6}$ See also Aristotle's mention of the parrotfish at Part. an. 675a4, which makes the unique aspect of this fish clearer: it does have teeth in only one jaw, just as viviparous fourstomached cud-chewing ruminants do, hence the apparent chewing motion that the fish makes. The animal's stomach, however, confirms that the parrotfish is really a fish, at least according to Aristotle's taxonomy. 
discussion it is not clear how hard lion bones are in relation to those of other animals, or why they might be able to give off sparks at all. ${ }^{57}$ Once again, we see that the paradoxographer's careful act of adaptation manages to shift the emphasis of the original source text by focusing on an unusual zoological example which constitutes a definite exception to the more general rules and principles being outlined in the broader discussion as a whole.

The mobility of cattle horns in Phrygia also turns out to be a more logical phenomenon than first imagined, as Aristotle's longer discussion of the general composition of animal horns makes clear. At Historia animalium 5I7a20-3 he observes that 'most horns are hollow from the point they attach to the bone inside them growing out from the head, but solid at the tip' ( $\tau \tilde{\omega} \nu \delta \dot{\varepsilon}$

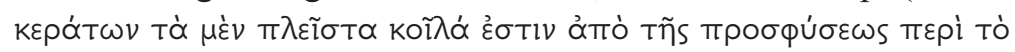

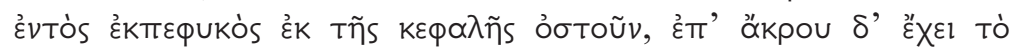

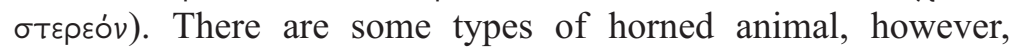
which are exceptions to this general rule, like certain cattle

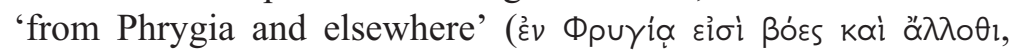
5I7a28-9), whose horns attach to the skin of the head rather than to the solid bone of the skull. For this reason they freely

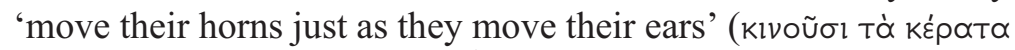

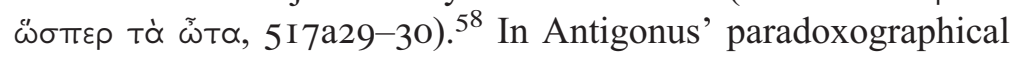
version of this observation, however, the relatively straightforward explanation that horns are able to move if they are attached to movable skin as opposed to fixed bone is completely excised. Moreover, Aristotle's note that such animals are found in Phrygia

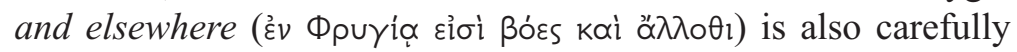
neglected, giving the impression that the wiggly-horned Phrygian

57 Aristotle does in fact elaborate upon the reasons why lion bones are naturally so exceptionally hard in even more detail at Part. an. 655aI2-I6. There it is explained that the bones of bulky male flesh-eating animals are naturally hard because these creatures must obtain food by fighting: as perhaps the fiercest flesh-eating animal, the lion's bones are therefore naturally the hardest.

${ }^{8}$ Aristotle may be referring to cattle with scurs (known as Wackelhörner in German), movable 'horns' created by incomplete horn growth which is not attached to the skull (see Kyselý (20I0) I24I-6 for a discussion of the 'loose horns' phenomenon in cattle and archaeological evidence for such bovids in Eneolithic central Europe). For other ancient accounts of the movable horns of Phrygian cattle, see Oppian, Cynegetica 2.905 and Plin. $H N$ II.I25; cf. Ael. $N H 2.20$ (describing the movable horns of cattle in Erythrae) and I 7.45 (on the movable horns of Ethiopian flesh-eating bulls; cf. also Diod. Sic. 3.35.7). 
animals are a truly exceptional thauma worthy of particular wonder. As these examples show, Antigonus has not arbitrarily plucked sentences from his source text in an unexamined fashion. Instead, the paradoxographer has carefully chosen his thaumata by picking up on natural exceptions and then systematically stripping them of their carefully constructed explanatory framework. As suggested above, this deliberate stripping of explanation and context acts to heighten a sense of paradox and wonder through the deliberate suppression of any sense of the causes of each given phenomenon, acting in turn as a means of restimulating the primordial Aristotelian wonder felt at the initial observation of strange and inexplicable zoological specimens or processes. If we read Hellenistic paradoxographical collections with this kind of deliberate treatment of their source texts in mind, these marvel-collections begin to make more sense as interlocutors in a philosophical tradition which situates its origins in thauma itself.

\subsection{Textual Thaumata: Paradoxography and the Poetics of Hellenistic Literature}

There is one other important respect in which the paradoxographical collection can be seen as echoing contemporary Hellenistic intellectual and literary trends. The brevity and lack of any contextual framework associated with the thaumata created by the paradoxographer's preferred methods of excerption also align the paradoxographical collection with another contemporary textual genre: the literary epigram collection. In Chapter 2, it was noted that the connections between the content of Hellenistic paradoxographical collections and the Posidippus epigrams on the Milan Papyrus have recently been recognised, although the similarities of form apparent between the epigram collection and the paradoxographical collection have not yet been explored. ${ }^{59}$ In many respects the systematic stripping away of any contextual information that surrounded the thaumata of paradoxography in their source texts is akin to the manner in which the literary epigram's relative concision and absence of a clear context of utterance or

59 See Chapter 2, Section 4.

78 


\subsection{Textual Thaumata}

inscription encourages the reader to fill in resulting interpretative gaps, deriving pleasure from the imaginative engagement which the supplementation of contextual knowledge provokes: a process which Bing has termed Ergänzungsspiel (supplementation game) in relation to Hellenistic epigram. ${ }^{60}$ The restimulation of inquiry which the paradoxographical collection encourages through its manipulation of thauma bears many similarities to the response provoked by the Ergänzungsspiel of epigram, with the reader prompted to speculate about the possible causes of each marvel, and encouraged to try to fill in the now renewed gaps in explanation. This potentially starts the chain of philosophical inquiry afresh, with the possibility of eventually moving on to the contemplation of even weightier philosophical matters lying ahead.

Far from representing the shoddy end-product of an inadequate Hellenistic scientist trying and failing to produce a set of usable 'research notes', or of a shambolic historian missing the point when it comes to framing a coherent historical narrative, the paradoxographical collection becomes yet another manifestation of a complex engagement with intellectual, philosophical and literary trends on the part of Hellenistic scholars and poets. Furthermore, by entering the world of the paradoxographers, we witness a change in the conception of what an appropriate object of thauma might be in the Hellenistic age: now the text itself has cemented its place as possibly the most marvellous object of all. Far from being a manifestation of decline, the emergence of paradoxography as a mode of writing in the third century BCE attests to changing attitudes concerning the effects and causes of wonder itself.

${ }^{60}$ See Bing (1995) I I 5-3 I on Ergänzungsspiel in relation to Hellenistic epigram; cf. also Hunter (I992) I I 4 on the use of literary epigrams as 'a provocation to speculation'; this speculation becomes a hallmark of the genre as a whole; see also Meyer (2007) I87$2 \mathrm{IO}$. For the act of supplementation as an essential aspect of the aesthetics of Hellenistic art as well as poetry, see Zanker (2004) 72-IO2. 